\title{
Physical Accessibility for Disabled People: Analysis of Toilet Facilities in Primary Health Care Units
}

\author{
Aline Cruz Esmeraldo Áfio ${ }^{1 *}$, Luciana Vieira de Carvalho', Juliana Freitas Marques', \\ Paula Marciana Pinheiro de Oliveira², Paulo Cesar de Almeida ${ }^{3}$, Lorita Marlena Freitag Pagliuca ${ }^{1}$ \\ ${ }^{1}$ Nursing Department, Federal University of Ceará (UFC), Fortaleza, Brazil \\ ${ }^{2}$ University of International Integration of the Afro-Brazilian Lusophony (UNILAB), Redenção, Brazil \\ ${ }^{3}$ State University of Ceará (UECE), Fortaleza, Brazil \\ Email: *lineafio@hotmail.com, lucianavcarvalho@hotmail.com, juliana.fmarques@outlook.com, paulamarciana@yahoo.com.br, \\ pc2015almeida@gmail.com,pagliuca@ufc.br
}

How to cite this paper: Áfio, A.C.E., de Carvalho, L.V., Marques, J.F., de Oliveira, P.M.P., de Almeida, P.C. and Pagliuca, L.M.F. (2016) Physical Accessibility for Disabled People: Analysis of Toilet Facilities in Primary Health Care Units. Open Journal of Nursing, 6, 948-957.

http://dx.doi.org/10.4236/ojn.2016.611091

Received: October 18, 2016

Accepted: November 21, 2016

Published: November 24, 2016

Copyright $\odot 2016$ by authors and Scientific Research Publishing Inc. This work is licensed under the Creative Commons Attribution International License (CC BY 4.0).

http://creativecommons.org/licenses/by/4.0/

\section{(c) (i) Open Access}

\begin{abstract}
Background: Accessibility enables the effective participation of disabled persons in public and private areas and the use of urban equipment and street furniture. Objective: This study aimed to analyze the physical accessibility of toilet facilities in urban and rural primary health care units. Methods: It was a quantitative descriptive study conducted in 157 Primary Health Care Units of 16 municipalities in the Baturite Massif region, Ceará, Brazil. The study took place from August 2014 to May 2015, with a checklist type form, designed from the Technical Standard 9050 of the Brazilian National Standards Organization, specifying the ideal access conditions established by law to allow mobility of persons with physical disabilities. Data were processed through the Statistical Package for the Social Sciences software and organized into tables. Results: Toilets designed for physically disabled people were accessible as the location and signs (59.9\%), identified with symbols for males and females (57.3\%); however, the doorway width was smaller than needed to accommodate a wheelchair (77.7\%). Inside the bathroom, only the forward approach was possible (59.9\%). Grab bars positioned on the side and rear walls were inadequate or nonexistent (67.6\%); toilet seats (91.1\%) and toilet paper dispensers (96.2\%) were mostly in inaccessible heights; flush controls in appropriate height (59.2\%) and activated by light pressure (58\%). Sinks without pedestal (51\%), but higher than recommended (80.3\%) and without single handle faucets (95.6\%). It was verified that the toilets of basic health units located in urban areas had better accessibility conditions compared to those in rural areas. Conclusion: Results showed that the analyzed units presented physical inaccessibility in some toilet facilities, making it difficult or even
\end{abstract}


impossible the accessibility for the disabled. The inclusion of accessibility features in health services for this clientele provides equal opportunities and social inclusion.

\section{Keywords}

Health Services Accessibility, Disabled Persons, Toilet Facilities

\section{Introduction}

Accessibility concerns the physical conditions or the communication elements that enable safe and autonomous participation of people in public and private areas, in the use of urban equipment and street furniture, providing greater social inclusion and better quality of life [1] Ensuring the access of disabled people is an act that respects their freedom of movement, allowing them to use essential public services.

It is worth highlighting the difference between access and accessibility. Even though access complements accessibility, these are two distinct concepts, in which accessibility enables people to come to the environment, while access provides the appropriate use of services to achieve better results [2].

There are many challenges in evaluating the accessibility of specific groups, such as people with mobility issues in a particular urban space. Methods that are usually based on technical standards and legislation can be adapted to seek a broader approach to identify and understand accessibility, as well as the perception of the space and environment where these groups live [3].

Despite the extensive Brazilian law to guarantee the accessibility right to health care of disabled persons, most are not respected. Legislation focuses on basic precepts to promote accessibility to spaces and urban equipment, emphasizing the importance of architectural planning of facilities to ensure the universal right to access and quick and safe mobilization [4].

Nevertheless, the association between the dimensions of accessibility, both in terms of health services organization and geographical aspects, mediated by users' empowerment, has not been achieved, as well as analyzing the reasons why these problems remain [5].

Health care accessibility of disabled people comprises a set of strategies and equipment incorporated and linked to the physical space. It should include practices and care that point to independence and social inclusion processes from the first interventions to the optimization of spaces available in health services [6].

Additionally, it refers to the characteristics of resources that facilitate or limit its use by potential clients, corresponding to the aspects of services with special significance when analyzed according to the impact they have on people's ability to use them. Therefore, accessibility is an important supply factor in explaining the variations of how the population uses health services, representing a crucial dimension in studies about equity in health systems [7]. 
Among the various locations offered to the population in primary health care services, access to toilet facilities should promote the independence of disabled persons, assuring their intimacy and privacy. Going to the bathroom can become an extremely difficult task, even impossible sometimes, when the right measures for the physically impaired or people with reduced mobility are not implemented [6].

Developing projects that strengthen the accessibility and designing manuals and routines for primary health care, to encourage the humanization through welcome practices, along with intersectoral actions, favor the expansion of comprehensive care [8].

By recognizing the legitimate rights of accessibility and social integration of disabled people, it is intended to contribute to mapping architectural barriers to their accessibility to toilet facilities of basic health services. Thus, this study seeks to contribute to the care and teaching in the field of nursing and areas of health sciences, human sciences, and engineering [9].

Given the importance of primary health care as the health system gateway, this work aims to analyze the physical accessibility to toilet facilities in urban and rural primary health care units.

\section{Methods}

It was a quantitative research of descriptive approach consisting of measurement procedures of the architectural conditions of toilet facilities that compose the physical structure of Primary Health Care Units located in the Baturité Massif region, in the State of Ceará, Brazil. This location was chosen due to the high prevalence of disabled persons in the population and lack of previous studies on the health services accessibility.

Study was conducted from August 2014 to May 2015. Data collection comprised 157 Primary Health Care Units distributed among the 16 municipalities of that region. The sample was extracted from the National Register of Health Institutions of the Ministry of Health, a system that provides data on the health care network in the Brazilian territory.

For data collection, a checklist tool entitled Record of Physical Accessibility to Health Units was used, constructed based on Technical Standard 9050 (NBR 9050) of the Brazilian National Standards Organization, which determines standard measures required to provide appropriate access conditions to buildings, furniture, spaces, and urban equipment to the mobility of disabled persons [10].

The instrument is structured in two parts, the first relating to the unit's identification data and the second containing topics on the characteristics of the various sectors that constitute the physical structure of health service units, particularly analyzing the topic Toilet facilities with the following items: location; signs; use for both sexes; doorway width; wheelchair maneuvering areas (forward, $90^{\circ}, 180^{\circ}$, and $360^{\circ}$ rotation, and free space); grab bars; toilet seats; toilet paper dispensers; flush control; sink and faucet. Response options were: Accessible (A), accessible structure; Inaccessible (I), inaccessible structure; Absence (AB), without the structure to be evaluated; Does not apply (DNA), the place did not require the structure; Renovation (RE), rooms being renovated; Not 
Collected (NC), place closed at the time of collection; and Without the Place (WP), the location to be assessed did not exist.

During data collection, materials such as measuring tapes and digital cameras were used, and all the survey participants were trained for proper filling of the instrument and correct use of support materials.

Data obtained were entered into spreadsheet, through Microsoft Excel', in two databases in order to avoid any typing errors. For data analysis, the Statistical Package for the Social Sciences (SPSS) software version 20.0 was used, and data were later presented in tables with absolute and relative frequencies. The Binomial test was applied to compare the variables Accessible and Inaccessible, Chi-square test to assess the association between the variables of interest, and Odds Ratio (OR) to measure the magnitude of the effect, adopting a $95 \%$ confidence interval $(95 \% \mathrm{CI})$. The level of statistical significance was set at $5 \%(\mathrm{p}<0.05)$.

The Research Ethics Committee of the University of International Integration of the Afro-Brazilian Lusophony (UNILAB) approved the study under protocol No. 652, 134/ 2014. The study followed the ethical and legal principles in accordance with resolution of the National Health Council, concerning and regulating the guidelines and rules involving research with human beings (Resolution No. 466, 2012). Authorization of the directors of health facilities was requested by signing the Free and Informed Consent Form (FICF).

\section{Results}

Table 1 shows that toilet facilities were accessible as the location and signs, with statistically significant differences ( $\mathrm{p}<0.001$ and 0.010 , respectively). Regarding the separation of bathrooms by gender, it was found that $57.3 \%$ were divided into male and female.

Of all toilet facilities, $77.7 \%$ have inaccessible doorways $(\mathrm{p}<0.001)$, despite presenting space to perform the $1.20 \mathrm{~m}$ forward approach $(\mathrm{p}=0.006)$. Nonetheless, in absolute majority, there were no obstacle-free space for maneuvering the wheelchair in $90^{\circ}, 180^{\circ}$ and $360^{\circ}$, thus being considered inaccessible $(\mathrm{p}<0.001)$.

Regarding the presence of horizontal bars on the side and rear walls, $67.6 \%$ were allocated inappropriately or non-existent, constituting the inaccessibility of this item with significant results $(\mathrm{p}=0.019)$.

Toilet seats and toilet paper dispensers were evaluated mostly as inaccessible to the physically disabled $(\mathrm{p}<0.001)$, considering they did not contain accessibility aspects, like appropriate height. Flush controls, however, were considered accessible as the height and activation by light pressure ( $\mathrm{p}=0.002$ and 0.006 , respectively).

Sinks presented accessibility aspects, such as the absence of pedestals (51\%), but the height and faucet type were inadequate $(\mathrm{p}=0.000)$.

Table 2 reveals that items with favorable accessibility results were from the urban units, with just one item from the rural area, appropriate flush control height ( $\mathrm{p}=$ 0.040). 
Table 1. Distribution of basic health units according to accessible and inaccessible items. Baturité Massif region, Ceará, Brazil, 2014.

\begin{tabular}{|c|c|c|c|c|c|c|}
\hline \multirow{2}{*}{ Variable } & \multicolumn{2}{|c|}{ Accessible } & \multicolumn{2}{|c|}{ Inaccessible } & \multirow{2}{*}{$\mathrm{p}$} & \multirow{2}{*}{$\begin{array}{c}\text { DNA/RE/NC } \\
\text { /WP (\%) }\end{array}$} \\
\hline & $\mathbf{n}$ & $\%$ & $\mathrm{n}$ & $\%$ & & \\
\hline Easy location & 125 & 79.6 & 30 & 19.1 & $<0.001$ & $2(1.3 \%)$ \\
\hline Signs & 94 & 59.9 & 61 & 38.9 & 0.010 & $2(1.3 \%)$ \\
\hline For both sexes & 90 & 57.3 & 65 & 41.4 & 0.054 & $2(1.3 \%)$ \\
\hline Doorway width of $80 \mathrm{~cm}$ & 25 & 15.9 & 122 & 77.7 & $<0.001$ & $10(6.4 \%)$ \\
\hline $1.20 \mathrm{~m}$ forward approach & 94 & 59.9 & 59 & 37.6 & 0.006 & $4(2.5 \%)$ \\
\hline $1.20 \times 1.20 \mathrm{~m} \mathrm{90}{ }^{\circ}$ maneuver & 52 & 33.1 & 101 & 64.3 & $<0.001$ & $4(2.5 \%)$ \\
\hline $1.20 \times 1.50 \mathrm{~m} 180^{\circ}$ maneuver & 36 & 22.9 & 117 & 74.5 & $<0.001$ & $4(2.5 \%)$ \\
\hline $1.50 \times 1.50 \mathrm{~m} 360^{\circ}$ maneuver & 30 & 19.1 & 123 & 78.3 & $<0.001$ & $4(2.5 \%)$ \\
\hline $1.20 \times 0.80 \mathrm{~m}$ free space & 35 & 22.3 & 118 & 75.2 & $<0.001$ & $4(2.5 \%)$ \\
\hline Grab bars on side and rear walls & 47 & 29.9 & 106 & 67.6 & 0.019 & $4(2.5 \%)$ \\
\hline $80 \mathrm{~cm}$ horizontal bars & 20 & 12.7 & 133 & 84.8 & 0.013 & $4(2.5 \%)$ \\
\hline Side bars $75 \mathrm{~cm}$ above the finish floor & 3 & 1.9 & 150 & 95.6 & $<0.001$ & $4(2.5 \%)$ \\
\hline Toilet seat $46 \mathrm{~cm}$ above the finish floor & 10 & 6.4 & 143 & 91.1 & $<0.001$ & $4(2.5 \%)$ \\
\hline $\begin{array}{l}\text { Toilet paper dispenser } 50 \text { to } 60 \mathrm{~cm} \\
\text { above the finish floor and } 15 \mathrm{~cm} \text { from } \\
\text { the front end }\end{array}$ & 2 & 1.3 & 151 & 96.2 & $<0.001$ & $4(2.5 \%)$ \\
\hline $\begin{array}{l}\text { Flush control at a maximum height of } \\
1 \mathrm{~m} \text { above the finish floor }\end{array}$ & 93 & 59.2 & 60 & 38.3 & 0.002 & $4(2.5 \%)$ \\
\hline $\begin{array}{l}\text { Flush control activated by light } \\
\text { pressure }\end{array}$ & 91 & 58.0 & 62 & 39.5 & 0.006 & $4(2.5 \%)$ \\
\hline Sink without pedestal & 80 & 51 & 73 & 46.5 & 0.181 & $4(2.5 \%)$ \\
\hline $\begin{array}{l}\text { Sink between } 78 \text { and } 80 \mathrm{~cm} \text { above the } \\
\text { finish floor }\end{array}$ & 27 & 17.2 & 126 & 80.3 & $<0.001$ & $4(2.5 \%)$ \\
\hline Single handle faucet & 3 & 1.9 & 150 & 95.6 & $<0.001$ & $4(2.5 \%)$ \\
\hline
\end{tabular}

p-value of the binomial test for comparing the variables accessible and inaccessible.

Items of the toilet facilities of basic health units associated with the urban area were signs $(\mathrm{OR}=4.6 ; \mathrm{p}<0.0001)$, forward approach $(\mathrm{OR}=2.2 ; \mathrm{p}=0.025), 90^{\circ}(\mathrm{OR}=3.9 ; \mathrm{p}$ $<0.0001), 180^{\circ}(\mathrm{OR}=5.4 ; \mathrm{p}<0.0001)$, and $360^{\circ}$ rotations $(\mathrm{OR}=6.6 ; \mathrm{p}<0.0001)$, and single handle faucet $(\mathrm{OR}=4.6 ; \mathrm{p}<0.0001)$. Therefore, they were more likely to have accessibility characteristics.

\section{Discussion}

Primary health care is the first occasion of user assistance in the health system, thus the assistance model should meet the specific needs of various population groups, including disabled people. Nevertheless, in Brazil, a difficult access of this public to primary care is verified, aggravated by the development of fragile, inconsistent, and discontinuous health actions, demonstrating that it does not meet their real needs [6]. 
Table 2. Percentage distribution of accessible locations of basic health units according to rural or urban area. Baturité Massif region, Ceará, Brazil, 2014.

\begin{tabular}{|c|c|c|c|c|}
\hline Variable & Rural & Urban & $\mathrm{OR}^{*}(95 \% \mathrm{CI})$ & $\mathrm{p}^{* *}$ \\
\hline Easy location & 83.3 & 76.9 & $0.7(0.3 ; 1.5)$ & 0.319 \\
\hline Signs & 46.7 & 80.0 & $4.6(2.2 ; 9.5)$ & $<0.0001$ \\
\hline For both sexes & 52.2 & 66.2 & $1.8(0.9 ; 3.4)$ & 0.083 \\
\hline Doorway width of $80 \mathrm{~cm}$ & 16.3 & 18.0 & $1.1(0.5 ; 2.7)$ & 0.780 \\
\hline $1.20 \mathrm{~m}$ forward approach & 53.9 & 71.9 & $2.2(1.1 ; 4.3)$ & 0.025 \\
\hline $1.20 \times 1.20 \mathrm{~m} 90^{\circ}$ maneuver & 21.3 & 51.6 & $3.9(1.9 ; 7.9)$ & $<0.0001$ \\
\hline $1.20 \times 1.50 \mathrm{~m} 180^{\circ}$ maneuver & 11.2 & 46.6 & $5.4(2.4 ; 12.3)$ & $<0.0001$ \\
\hline $1.50 \times 1.50 \mathrm{~m} 360^{\circ}$ maneuver & 7.9 & 35.9 & $6.6(2.6 ; 16.6)$ & $<0.0001$ \\
\hline $1.20 \times 0.80 \mathrm{~m}$ free space & 11.2 & 39.1 & $5.1(2.2 ; 11.6)$ & $<0.0001$ \\
\hline Grab bars on side and rear walls & 59.5 & 69.4 & $1.6(0.6 ; 4.1)$ & 0.373 \\
\hline $80 \mathrm{~cm}$ horizontal bars & 31.2 & 35.7 & $1.2(0.4 ; 3.6)$ & 0.714 \\
\hline Side bars $75 \mathrm{~cm}$ above the finish floor & 6.2 & 3.6 & $0.6(0.1 ; 6.5)$ & 0.635 \\
\hline Toilet seat $46 \mathrm{~cm}$ above the finish floor & 4.5 & 9.7 & $2.3(0.6 ; 8.4)$ & 0.208 \\
\hline $\begin{array}{l}\text { Toilet paper dispenser } 50 \text { to } 60 \mathrm{~cm} \\
\text { above the finish floor and } 15 \mathrm{~cm} \text { from } \\
\text { the front end }\end{array}$ & 3.4 & 0.0 & $0.6(0.5 ; 0.7)$ & 0.239 \\
\hline $\begin{array}{l}\text { Flush control at a maximum height of } \\
11 \mathrm{~m} \text { above the finish floor }\end{array}$ & 69.8 & 53.2 & $0.5(0.3 ; 0.9)$ & 0.040 \\
\hline $\begin{array}{l}\text { Flush control activated by light } \\
\text { pressure }\end{array}$ & 64.0 & 58.1 & $0.8(0.4 ; 1.5)$ & 0.468 \\
\hline Sink without pedestal & 50.6 & 62.9 & $1.7(0.8 ; 3.2)$ & 0.142 \\
\hline $\begin{array}{l}\text { Sink between } 78 \text { and } 80 \mathrm{~cm} \text { above the } \\
\text { finish floor }\end{array}$ & 21.0 & 16.1 & $0.7(0.3 ; 1.7)$ & 0.462 \\
\hline Single handle faucet & 0.0 & 4.8 & $0.4(0.3 ; 0.5)$ & 0.045 \\
\hline
\end{tabular}

${ }^{*}$ OR: Odds ratio; ${ }^{* *}$ Chi-square p-value.

The right to accessibility preserves the individual autonomy. In this sense, it is essential to evaluate the movements of disabled persons in health services, considering their independence, ease, and security in using the space, existing equipment, and furniture. Among the various sectors that compose the physical structure of health units, toilet facilities are one of the main areas that need adaptation to provide privacy, maintenance of bodily functions, and proper personal hygiene to users with reduced mobility.

In this study, inaccessibility was observed in most toilet facilities in health units, which causes disabled users to experience difficulties in using this space, in addition to dependence, stressful moments, embarrassment, discomfort, and losses in performing self-care. The location and signs of toilets met the standards of NBR 9050, since 79.6\% were in easily accessible locations and $59.9 \%$ had indicative toilet signs.

These points are worth highlighting because a study evaluating the infrastructure of health units in the state of Paraíba, Brazil, identified an opposite reality, observing that the bathrooms were not arranged in accessible locations, away from the main circula- 
tion and with inappropriate signage, representing one of the items with the most critical accessibility conditions [11].

It is noteworthy that the presence of indicative toilet signs predominated in units located in the urban area $(80.0 \%)$, showing greater effort to provide access to the different environments in the health facility through their identifications.

The Manual of Physical Structure of Basic Health Units, produced by the Brazilian Ministry of Health, establishes that the units must have separate toilet facilities for each sex, with at least one designed for disabled people, meeting the technical standards [12]. The majority (57.3\%) of toilet facilities were arranged separately for male and female, in accordance with the importance of respecting the privacy and following the existing rules in force regarding the architectural planning for structuring a health care unit.

Regarding the item doorways with minimum width of $80 \mathrm{~cm}$, inaccessibility prevailed in $77.7 \%$ of bathrooms, as they were narrow and prevented the passage of wheelchairs.

This finding corroborates a study conducted in the State of Paraíba, Brazil, which found that in $70 \%$ of the units, the bathroom doors prevented the access of the handicapped (Rocha et al., 2012). Inadequate doorways violate the concept of accessibility, since all individuals have equal rights to enter all physical spaces and enjoy the services provided autonomously [6].

Toilet facilities should have enough space to allow movement of wheelchair users and proper use of bathroom accessories by providing room for forward, $90^{\circ}, 180^{\circ}$, and $360^{\circ}$ transfer and approach maneuvers [10]. Most toilets were considered inaccessible for not having enough space for wheelchair movement, especially regarding rotational movements $\left(64.3 \%\right.$ for $90^{\circ}, 74.5 \%$ for $180^{\circ}$, and $78.3 \%$ for $\left.360^{\circ}\right)$, which prevents the independent and private use of the environment.

It is worth mentioning that the units with accessibility in these items were located predominantly in urban areas, indicating greater infrastructure of urban units compared to those in rural areas, since toilet facilities require a greater space to allow the various rotational movements.

The lack or inadequate placement of grab bars also hinders the use of bathrooms. Aimed at offering support, balance, and safety during the use of toilet accessories, they require length and mounting height in compliance with the technical standard [10]. A total of $67.6 \%$ of toilets had inaccessible bars on the side and rear walls, as they were installed in improper height.

These elements were also observed as inaccessible in a study that analyzed accessibility issues in primary health care services in the State of Pernambuco, Brazil, which verified that $97 \%$ of the units did not have accessible toilets, highlighting the absence of grab bars in bathrooms [13].

Regarding toilet seats, they were inaccessible because they did not have a $46 \mathrm{~cm}$ height above the finish floor (91.1\%). Additionally, toilet paper dispensers (96.2\%) were non-standard; they should be at a height between 50 and $60 \mathrm{~cm}$ above the finish floor and $15 \mathrm{~cm}$ from the front end [10].

Sinks were also evaluated. Among those with physical accessibility items, it is hig- 
hlighted that $51 \%$ had sink without pedestal, thus allowing the wheelchair approach. Nonetheless, when measuring its height, $80.3 \%$ were inaccessible, as well as the faucets, which should be of single handle type.

Evaluation of physical accessibility of bathrooms in 27 schools of Chapecó, Santa Catarina, Brazil, identified that only 13 had toilet facilities adapted for disabled people. Different from the present study, $76.92 \%$ of analyzed bathrooms had suspended washbasins from $78 \mathrm{~cm}$ to $80 \mathrm{~cm}$ above the finish floor [14].

This type of evaluation is also common in other environments, such as long-term care facilities for the elderly. A study conducted in Portugal in this kind of institution detected that the position of sanitary equipment also constituted a limiting agent, hindering the proper use by persons with reduced mobility, besides the restricted access to the toilet, resulting in physical constraints. As for the sinks, they are lower than required by legislation and do not have single handle faucets [15].

The lack of accessible toilets for disabled people is evident. When asked, users themselves reported being unaware of fully accessible toilets for disabled persons in health services, because even if they exist, they are inappropriate for use [16].

People with physical disabilities have several mobility limitations, ranging from the inability to turn on a faucet to depend on a wheelchair for locomotion. This diversification implies an underreporting of this public, since many reject the international symbol of accessibility, represented by a wheelchair. The concept accepted by most of this population consists of people with limited mobility, not disabled persons, and they reject being identified as wheelchair users. In this context, they do not exercise their rights [17].

Toilets designed for physically disabled people were accessible as the location and signs, identified with symbol for male and female, but with doorway narrower than required to accommodate a wheelchair. Inside the bathroom, only the forward approach was available.

Grab bars on the side and rear walls were inadequately positioned or non-existent; toilet seats and toilet paper dispensers were mostly in inaccessible heights; flush controls in proper height and activated through light pressure. Sinks without pedestal, but higher than recommended and without single handle faucets. It was found that the toilet facilities in basic health units located in urban areas had better access conditions than those in rural areas.

With this purpose, it is imperative to investigate health services access barriers to support health planning. Information about the access of people with disabilities or mobility restriction in the Brazilian health system are incipient, especially in the socioeconomically disadvantaged regions. Thus, there are few indicators that assist in monitoring and evaluating the performance of the health system, essential tools for planning actions [18].

\section{Conclusions}

Regarding the health sector, the access of disabled persons is still incipient, since archi- 
tectural barriers are easily observed in health care services, constituting obstacles to health care. Awareness and commitment of leaders, managers, and professionals need to be established to create favorable spaces to universal health care.

It is worth highlighting that a report describing the problems identified in the toilet facilities of health units was made and delivered to the leaders of the municipalities. Nevertheless, since this is a cross-sectional study, a new assessment did not take place. Thus, it is suggested to conduct a longitudinal research to verify the occurrence of any changes after this study.

Although limited in assessing only the toilet facilities of health units in a specific region, this study showed that physical accessibility should be considered in any location, since eliminating these barriers provides significant value to this population in using health services, enabling equality and equity for disabled people. Inclusive awareness and sensitivity to the reality of this group are essential to meet their basic and specific human needs.

\section{References}

[1] Decreto n. 7.612, de 17 de novembro de 2011 (2011) Plano Nacional dos Direitos da Pessoa com Deficiência-Viver sem Limite. Diário Oficial da União. Ministério da Saúde, Brasília.

[2] Starfield, B. (2002) Atenção Primária: Equilíbrio entre necessidades de saúde, serviços e tecnologia. Ministério da Saúde, Brasília. http://bvsms.saude.gov.br/bvs/publicacoes/atencao_primaria_p1.pdf

[3] Machado, M.F. and Lima, J.P. (2015) Avaliação multicritério da acessibilidade de pessoas com mobilidade reduzida: Um estudo na região central de Itajubá (MG). Revista Brasileira de Gestão Urbana, 7, 368-382.

http://www.scielo.br/scielo.php?script=sci_abstract\&pid=S2175-33692015000300368\&lng= en\&nrm=iso\&tlng=en

[4] Carvalho, L.V., Áfio, A.C.E., Júnior Rodrigues, J.C., Rebouças, C.B.A. and Pagliuca, L.M.F. (2014) Advances in Health Promotion for People with Disabilities and the Laws of Brazil. Health, 6, 2365-2374. http://file.scirp.org/Html/1-8203147_50396.htm https:/doi.org/10.4236/health.2014.618272

[5] Amaral, F.L.J.S., Holanda, C.M.A., Quirino, M.A.B., Nascimento, J.P.S., Neves, R.F., Ribeiro, K.S.Q.S. and Alves, S.B. (2012) Accessibility for People with Disabilities or Permanent Mobility Restrictions to the Unified Health System. Ciênc Saúde Coletiva, 17, 1833-1840. http://www.scielo.br/scielo.php?script=sci_arttext\&pid=S1413-81232012000700022

[6] Girondi, J.B.R. and Santos, S.M.A. (2011) Deficiência física em idosos e acessibilidade na atenção básica em saúde: Revisão integrativa da literatura. Revista Gaúcha de Enfermagem (Online), 32, 378-384. http://www.scielo.br/pdf/rgenf/v32n2/a23v32n2.pdf

[7] Donabedian, A. (1973) Aspects of Medical Care Administration. Harvard University Press, Boston.

[8] Oliveira, F.S., Almeida, L.G.N., Oliveira, M.A.S., Gil, G.B., Cunha, A.B.O., Medina, M.G. and Pereira, R.A.G. (2012) Access to Primary Health Care in a Sanitary District of Salvador. Ciênc Saúde Coletiva, 17, 3047-3056.

http://www.scielo.br/scielo.php?script=sci_abstract\&pid=S1413-81232012001100021\&lng= en\&nrm=iso\&tlng=en

[9] Vasconcelos, L.R. and Pagliuca, L.M.F. (2006) Demarcation of the Accessibility of the Han- 
dicapped to a Basic Health Services. Escola Anna Nery, 10, 494-500.

http://www.scielo.br/scielo.php?script=sci_abstract\&pid=S1414-81452006000300019\&lng= en\&nrm=iso\&tlng=en

[10] Associação Brasileira de Normas Técnicas (2004) NBR 9050: Acessibilidade a edificações, mobiliário, espaços e equipamentos urbanos. Associação Brasileira de Normas Técnicas, Rio de Janeiro.

http://www.pessoacomdeficiencia.gov.br/app/sites/default/files/arquivos/\%5Bfield_generico _imagens-filefield-description\%5D_24.pdf

[11] Rocha, A.C.D., Sousa, C.P.C., Queiroz, D. and Pedraza, D.F. (2012) Primary Health Care Evaluation: A New Approach. Revista de administração em saúde (RAS). Revista de Administração em Saúde, 14, 71-79.

http://www.scielo.br/scielo.php?script=sci_arttext\&pid=S0104-12902011000400010

[12] Ministério da Saúde (2008) Manual de estrutura física das unidades básicas de saúde: saúde da família (2a ed.). Ministério da Saúde, Brasília.

http://bvsms.saude.gov.br/bvs/publicacoes/manual_estrutura_fisica_ubs.pdf

[13] Albuquerque, M.S.V., Lyra, T.M., Farias, S.F., Mendes, M.F.M. and Martelli, P.J.L. (2014) Acessibilidade aos serviços de saúde: Uma análise a partir da Atenção Básica em Pernambuco. Saúde Debate, 38, 182-194.

http://www.scielo.br/scielo.php?script=sci_arttext\&pid=S0103-11042014000600182 https:/doi.org/10.5935/0103-1104.2014s014

[14] Gallo, E.C., Orso, K.D. and Fiório, F.B. (2011) Analysis of the Accessibility of People with Physical Deficiency in the Schools of Chapecó-SC and the Role of Physiotherapist in the School Setting. O Mundo da Saúde, 35, 201-207.

http://bvsms.saude.gov.br/bvs/artigos/analise_acessibilidade_pessoas_deficiencia_fisica_esc olas.pdf

[15] Paiva, M.M.B. and Villarouco, V. (2012) Acessibility in Collective Housing for the Elderly: A Case Study in Portugal. Work, 41, 4174-4179. https://www.ncbi.nlm.nih.gov/pubmed/22317362

[16] Castro, S.S., Lefèvre, F., Lefèvre, A.M.C. and Cesar, C.L.G. (2011) Acceso a los servicios de salud por personas con discapacidad. Revista de Saúde Pública, 45, 99-105. http://www.scielo.br/scielo.php?script=sci_arttext\&pid=S0034-89102011000100011\&lng=pt \&thlng=pt https:/doi.org/10.1590/S0034-89102010005000048

[17] Pagliuca, L.M.F., Oliveira, P.M.P., Mariano, M.R., Silva, J.M., Almeida, P.C. and Oliveira, G.O.B. (2015) Pessoa com deficiência: Construção do conceito por esta população. Revista Rene, 16, 705-713. http://www.periodicos.ufc.br/index.php/rene/article/view/2835

[18] Szwarcwald, C.L., Mendonça, M.H.M. and Andrade, C.L.T. (2006) Indicadores de atenção básica em quatro municípios do Estado do Rio de Janeiro, 2005: Resultados de inquérito domiciliar de base populacional. Ciência \& Saúde Coletiva, 11, 643-655.

http://www.scielo.br/pdf/csc/v11n3/30980.pdf https:/doi.org/10.1590/S1413-81232006000300013 
Submit or recommend next manuscript to SCIRP and we will provide best service for you:

Accepting pre-submission inquiries through Email, Facebook, LinkedIn, Twitter, etc. A wide selection of journals (inclusive of 9 subjects, more than 200 journals)

Providing 24-hour high-quality service

User-friendly online submission system

Fair and swift peer-review system

Efficient typesetting and proofreading procedure

Display of the result of downloads and visits, as well as the number of cited articles

Maximum dissemination of your research work

Submit your manuscript at: http://papersubmission.scirp.org/

Or contact ojn@scirp.org 